\title{
Parthenolide inhibits hydrogen peroxide-induced osteoblast apoptosis
}

\author{
WEIHUAN MAO ${ }^{1}$ and ZIGUAN ZHU ${ }^{2}$ \\ ${ }^{1}$ Department of Orthopedics, The Fifth People's Hospital of Yuhang District, Hangzhou, Zhejiang 311100; \\ ${ }^{2}$ Department of Hand and Reconstructive Surgery, Zhejiang Provincial People's Hospital, \\ People's Hospital of Hangzhou Medical College, Hangzhou, Zhejiang 310014, P.R. China
}

Received June 28, 2017; Accepted December 11, 2017

DOI: $10.3892 / \mathrm{mmr} .2018 .8908$

\begin{abstract}
Parthenolide is a natural product from the shoots of Tanacetum parthenium that has been demonstrated to have immunomodulatory effects in a number of diseases. The present study aimed to determine the effect and mechanism of parthenolide on the apoptotic ability of $\mathrm{H}_{2} \mathrm{O}_{2}$-induced osteoblasts. Cell viability was analyzed with a MTT assay and the apoptotic rate was subsequently measured using flow cytometry. The activity of the antioxidative enzymes superoxide dismutase (SOD) and glutathione peroxidase (GPX), and the serum marker enzymes alkaline phosphatase (ALP), malondialdehyde (MDA) and lactate dehydrogenase (LDH) was measured. Reverse transcription-quantitative polymerase chain reaction and western blot analyses were performed to analyze the expression levels of osteogenesis and oxidative stress-associated genes. The results indicated that parthenolide increased cell viability and inhibited the apoptosis of $\mathrm{H}_{2} \mathrm{O}_{2}$-induced osteoblasts. Parthenolide decreased the levels of reactive oxygen species, MDA, LDH and ALP. SOD and GPX levels were increased by parthenolide in $\mathrm{H}_{2} \mathrm{O}_{2}$-induced osteoblasts. This suggested that parthenolide may break the equilibrium state of oxidative stress and inhibit cellular apoptosis. Parthenolide additionally increased the expression levels of oxidative stress-associated genes, including nuclear factor erythroid 2 like 2, hemeoxygenase- 1 and quinone oxidoreductase 1 in $\mathrm{H}_{2} \mathrm{O}_{2}$-induced osteoblasts. Furthermore, parthenolide increased the expression of osteogenesis-associated genes, including runt-related transcription factor 2, osteopontin, osteocalcin and collagen 1 in $\mathrm{H}_{2} \mathrm{O}_{2}$-inducedosteoblasts. Therefore, it was concluded that parthenolide may be used in the treatment of osteoporosis.
\end{abstract}

Correspondence to: Dr Ziguan Zhu, Department of Hand and Reconstructive Surgery, Zhejiang Provincial People's Hospital, People's Hospital of Hangzhou Medical College, 158 Shangtang Road, Hangzhou, Zhejiang 310014, P.R. China

E-mail: zhuziguan@sina.com

Key words: parthenolide, hydrogen peroxide, oxidative stress, osteoblast, apoptosis

\section{Introduction}

Osteoporosis is among the most common health problems in the elderly (1). Normal calcium homeostasis and supplementation are associated with good bone health (2). However, it has been demonstrated that calcium supplementation may cause a variety of adverse conditions, including cardiovascular disease, constipation and kidney stone development $(3,4)$. Therefore, the discovery of novel osteoporosis therapies is of high importance.

Cellular apoptosis may be induced by a number of factors $(5,6)$. Among the most important factors is oxidative stress (7). Oxidative stress has been confirmed to be associated with osteonecrosis $(8,9)$. Hydrogen peroxide $\left(\mathrm{H}_{2} \mathrm{O}_{2}\right)$ is a strong oxidizer which is able to induce cells to produce large amounts of reactive oxygen species (ROS) (10). ROS are produced in mitochondria as normal products of cellular metabolism. Elevated ROS is related to oxidative stress, causing cellular dysfunction and apoptosis $(11,12)$. ROS may damage double-stranded DNA, leading to abnormal variation $(13,14)$ and may additionally induce oxidative stress-induced apoptosis in tissues $(15,16) . \mathrm{H}_{2} \mathrm{O}_{2}$ is a key metabolite of oxidation reactions and, therefore, has critical involvement in the pathology of diseases mediated by oxidative stress $(15,16)$. Accumulating evidence has indicated that $\mathrm{H}_{2} \mathrm{O}_{2}$ may regulate cell function and induce cell death (17). $\mathrm{H}_{2} \mathrm{O}_{2}$ may additionally penetrate the cell membrane and act as a secondary messenger in signal transduction pathways (18). A previous study indicated that the manner of $\mathrm{H}_{2} \mathrm{O}_{2}$-induced cell death is associated with cell type, $\mathrm{H}_{2} \mathrm{O}_{2}$ concentration and the type of stimulation received (19).

Parthenolide is a traditional medicine with immunomodulatory effects (20). It has additionally been demonstrated to have the potential to treat certain types of cancer, including leukemia, and hepatic and breast cancer (21-24). Parthenolide is able to regulate multiple cellular and molecular signals in order to induce tumor cell apoptosis (25). It may additionally regulate the expression of the apoptosis regulator Bcl-2 (Bcl-2) protein family and caspases (25), and promote the loss of mitochondrial function (26). This evidence highlights the potential use of parthenolide in tumor therapy.

The specific effects of parthenolide on osteoblasts are not completely understood. Therefore, the purpose of the present study was to investigate the effect of parthenolide on osteoblast 
proliferation and apoptosis. First, the effects of parthenolide on osteoblast viability and $\mathrm{H}_{2} \mathrm{O}_{2}$-induced apoptosis were demonstrated. The influence of parthenolide on the expression of ROS, malondialdehyde (MDA), lactate dehydrogenase (LDH), alkaline phosphatase (ALP), superoxide dismutase (SOD) and glutathione peroxidase (GPX) in $\mathrm{H}_{2} \mathrm{O}_{2}$-inducedosteoblastswas additionally investigated. The regulation of oxidative stress-associated and osteogenesis-associated gene expression by parthenolide was subsequently analyzed. The results of the present study indicated that parthenolide may be used as a therapy for osteoporosis.

\section{Materials and methods}

Osteoblast sample. Osteoblasts were acquired from an 8-year-oldpatient with developmental dislocation of the hip. The operation was performed in department of orthopedics, the Fifth People's Hospital of Yuhang District, Hangzhou, Zhejiang in August, 2016. Informed consent was obtained from the patient and the patient's guardian. The present study was approved by The Ethics Committee of The Fifth People's Hospital of Yuhang District (Hangzhou, China). During the surgery, $\sim 1.5 \mathrm{~cm}^{2}$ of the cancellous bone of the iliac crest was removed and placed in Dulbecco's modified Eagle's medium/F12 (DMEM/F12; Thermo Fisher Scientific, Inc., Waltham, MA, USA) with $15 \%$ newborn calf serum (Thermo Fisher Scientific, Inc.) in sterile conditions.

Separation and cultivation of osteoblasts. The bone surface-attached connective tissues were eliminated and repeatedly washed with PBS. The bone tissue was cut $\left(1 \mathrm{~mm}^{3}\right)$ and washed with PBS. The bone tissue was subsequently digested with $0.25 \%$ trypsin (Thermo Fisher Scientific, Inc.) for $30 \mathrm{~min}$ at $37^{\circ} \mathrm{C}$, and $0.1 \%$ collagenase type II (Thermo Fisher Scientific, Inc.) for $1 \mathrm{~h}$ at $37^{\circ} \mathrm{C}$. The supernatant was collected and centrifuged at $1,000 \mathrm{x}$ g for $10 \mathrm{~min}$ at $4^{\circ} \mathrm{C}$. Cell deposits were placed in DMEM/F12 (Thermo Fisher Scientific, Inc.) with $15 \%$ newborn calf serum (Thermo Fisher Scientific, Inc.).

Cell treatment. Osteoblasts at a density of 10,000 cells were treated with PBS (control) and increasing concentrations of parthenolide $(0,5,10,15,20,25$ and $30 \mu \mathrm{M})$ for 24 and $48 \mathrm{~h}$. Osteoblasts were seeded into 6 -well plates at a concentration of $3 \times 105$ cells $/ \mathrm{ml}$ and treated with PBS, $0.8 \mathrm{mmol} / 1 \mathrm{H}_{2} \mathrm{O}_{2}$ or $0.8 \mathrm{mmol} / 1 \mathrm{H}_{2} \mathrm{O}_{2}$ and parthenolide $(5,10$ and $20 \mu \mathrm{M})$ for $24 \mathrm{~h}$.

ALP staining. Osteoblasts $(50,000$ cells/well) were seeded in 24-well plates and induced in a humidified incubator for $24 \mathrm{~h}$ at $37^{\circ} \mathrm{C}$. ALP activity was detected using the ALP staining kit (Merck KGaA, Darmstadt, Germany), according to the manufacturer's protocol. Osteoblasts were observed under a Wild Heerbrugg M400 Zoom Makroskop (Wild Heerbrugg, Heerbrugg, Switzerland) at x200 magnification.

Reverse transcription-quantitative polymerase chain reaction (RT-qPCR) assay. Total RNA was obtained using TRIzol (Thermo Fisher Scientific, Inc.), and RNA was reverse-transcribed to cDNA using a Revert Aid First Strand cDNA Synthesis kit (Thermo Fisher Scientific, Inc.) with random primers, according to the manufacturer's protocol.
SYBR-Green PCR Master Mix kit (Takara Biotechnology Co., Ltd., Dalian, China) was used to detect the mRNA expression levels, and the assay was performed on an ABI 7500 system (Thermo Fisher Scientific, Inc.). Thermocycling conditions were: $95^{\circ} \mathrm{C}$ for $15 \mathrm{sec}$; 40 cycles at $95^{\circ} \mathrm{C}$ for $10 \mathrm{sec}, 59^{\circ} \mathrm{C}$ for $10 \mathrm{sec}$ and $72^{\circ} \mathrm{C}$ for $15 \mathrm{sec}$. The relative mRNA expression levels were normalized to GAPDH. The data were analyzed using the $2^{-\Delta \Delta C t}$ method (27). The primer sequences were as follows: Bcl-2 forward, 5'-GCCTTCTTTGAGTTCGGTGG-3' and reverse, 5'-GAAATCAAACAGAGGCCGCA-3'; apoptosis regulator BAX (Bax) forward, 5'-GAGCTGCAGAGG ATGATTGC-3' and reverse, 5'-CCAATGTCCAGCCCATGA TG-3'; runt related transcription factor 2 (Runx2) forward, 5'-CTGTGGTTACTGTCATGGCG-3' and reverse, 5'-AGG TAGCTACTTGGGGAGGA-3'; osteopontin (OPN) forward, 5'-ACTGATTTTCCCACGGACCT-3' and reverse, 5'-CTC CTCGCTTTCCATGTGTG-3'; osteocalcin (OCN) forward, 5'-CTCACACTCCTCGCCCTATT-3' and reverse, 5'-AAC TCGTCACAGTCCGGATT-3'; collagen 1 (Col-1) forward, 5'-TCATTCCGCAAACCCACTTG-3' and reverse, 5'-CCC CAATCGAGAAGCCATTG-3'; nuclear factor erythroid 2 like 2 (Nrf2) forward, 5'-GGTTGCCCACATTCCCAAAT-3' and reverse, 5'-AGCAATGAAGACTGGGCTCT-3'; heme oxygenase 1 (HO1) forward, 5'-TTCAGAAGGGTCAGGTGT CC-3' and reverse, 5'-CAGTGAGGCCCATACCAGAA-3'; NAD (P) H quinone oxidoreductase 1 (NQO1) forward, 5'-CCTTCCGGAGTAAGAAGGCA-3' and reverse, 5'-TCT CCAGGCGTTTCTTCCAT-3'; and GAPDH forward, 5'-GCC ATCACAGCAACACAGAA-3' and reverse, 5'-GCCATACCA GTAAGCTTGCC-3'.

Western blot analysis. Total protein was extracted using radioimmunoprecipitation assay buffer (Beyotime Institute of Biotechnology, Shanghai, China) with a protease and phosphatase inhibitor cocktail (Thermo Fisher Scientific, Inc., Waltham, MA, USA). The concentration was measured using the Pierce Bicinchoninic Acid Protein Assay kit (Thermo Fisher Scientific, Inc.) and detected using a protein reagent (Bio-Rad Laboratories, Inc., Hercules, CA, USA). Proteins $(30 \mu \mathrm{g})$ were separated on a $10 \%$ SDS-PAGE gel and transferred to polyvinylidene difluoride membranes (PerkinElmer Inc., Waltham, MA, USA). The membranes were blocked with 5\% low-fat milk (BD Biosciences, Franklin Lakes, NJ, USA) for $2 \mathrm{~h}$ at room temperature and subsequently incubated with the following primary antibodies overnight at $4^{\circ} \mathrm{C}$ : Anti-GAPDH (1:2,000; cat. no. ab8245; Abcam, Cambridge, UK), anti-Bax (1:1,000; cat. no. ab32503; Abcam), anti-Bcl-2 (1:1,000; cat. no. ab32124; Abcam), anti-Runx2 (1:1,500; cat. no. ab23981; Abcam), anti-OPN (1:1,500; cat. no. ab166709; Abcam), anti-OCN (1:1,500; cat. no. ab93876; Abcam), anti-Col-1 (1:1,000; cat. no. ab6308; Abcam), anti-Nrf2 (1:1,000; cat. no. ab62352; Abcam), anti-HO1 (1:1,200; cat. no. ab69544; Abcam) and anti-NQO1 (1:1,000; cat. no. ab28947; Abcam). The membranes were incubated with horseradish peroxidase (HRP)-conjugated secondary antibody (1:1,000; cat. no. ab97165; Abcam) for $2 \mathrm{~h}$ at room temperature. The protein expression levels were detected using the enhanced chemiluminescence substrate kit (Thermo Fisher Scientific, Inc.) and the enhanced chemiluminescence detection system (GE Healthcare, Chicago, IL, USA). The densitometric analysis 
was performed by Labworks Software (version 4.5; UVP, Inc., Upland CA, USA).

ROS, SOD, MDA, GPX and LDH activity detection. Osteoblasts were treated with PBS, $0.8 \mathrm{mmol} / 1 \mathrm{H}_{2} \mathrm{O}_{2}$ or $0.8 \mathrm{mmol} / 1 \mathrm{H}_{2} \mathrm{O}_{2}$ and parthenolide $(5,10$ and $20 \mu \mathrm{M})$ for 12 , 24 and $48 \mathrm{~h}$. The fluorescent dye dihydroethidium (DHE; cat. 309800; Merck KGaA, Darmstadt, Germany) was used to measure ROS activity, as described previously (28). Treated cells were incubate $\mathrm{d}$ with $2.5 \mathrm{mmol} / 1 \mathrm{DHE}$ for $25 \mathrm{~min}$ at $37^{\circ} \mathrm{C}$. Cells were subsequently washed with PBS, digested with $0.25 \%$ trypsin (Sigma-Aldrich; Merck KGaA) and incubated with DHE. The results were detected by using flow cytometry equipped with an argon laser and Cell Quest ${ }^{\mathrm{TM}}$ software (version 3.3; BD Biosciences, Franklin Lakes, NJ, USA). The experiment was repeated at least three times. SOD and MDA activity was detected using a commercial kit (Sigma-Aldrich; Merck KGaA) (29) and a MDA activity assay kit (Nanjing Jiancheng Bioengineering Institute, Nanjing, China), respectively, according to the manufacturers' protocols. LDH activity was detected using a diagnostic kit (cat. no. GL2623; Randox Laboratories Ltd., Crumlin, UK), according to the method of Cabaud and Wroblewski (30). GPX enzyme activity was detected using the cellular GPX assay kit (Sigma-Aldrich; Merck KGaA) as described previously (31). The colorimetric reactions of LDH and GPX were determined using a microplate spectrophotometer system (BioRad-680, Bio-Rad Laboratories, Inc.) at 440 and $412 \mathrm{~nm}$, respectively.

ELISA analysis. Osteoblasts were treated with PBS (control), $0.8 \mathrm{mmol} / 1 \mathrm{H}_{2} \mathrm{O}_{2}$ or $0.8 \mathrm{mmol} / 1 \mathrm{H}_{2} \mathrm{O}_{2}$ and parthenolide $(5,10$ and $20 \mu \mathrm{M})$ for 12,24 and $48 \mathrm{~h}$. Treated osteoblasts were subsequently washed with PBS and centrifuged at $1,000 \mathrm{x}$ g for $5 \mathrm{~min}$ at $4^{\circ} \mathrm{C}$. The culture supernatant $(500 \mu \mathrm{l})$ was harvested and ALP activity was measured using an ELISA kit (cat. AR001, R\&D Systems, Minneapolis, MN, USA), according to the manufacturer's protocol. A 96-well plate was incubated with anti-ALP (1:1,000, cat. no. ab83259; Abcam) for $1 \mathrm{~h}$ at $37^{\circ} \mathrm{Cand}$ subsequently incubated with HRP-conjugated secondary antibody (1:5,000; cat. no. ab97165; Abcam) for $1 \mathrm{~h}$ at $37^{\circ} \mathrm{C}$. The absorbance was measured at $450 \mathrm{~nm}$ using a Multiskan GO microplate spectrophotometer (Thermo Fisher Scientific, Inc.).

Cell viability assay. Treated osteoblasts $\left(2 \times 10^{3}\right.$ cells/well $)$ were seeded into a 96 -well plate and maintained at $37^{\circ} \mathrm{C}$ for 12,24 and $48 \mathrm{~h}$. At the indicated time-points $(12,24$ and $48 \mathrm{~h}$ ), $15 \mu \mathrm{l}$ MTT solution (5 mg/ml) was added into each well, respectively. Following incubation for $4 \mathrm{~h}$, cells were treated with $150 \mu \mathrm{l}$ dimethylsulfoxide. The absorbance was measured using a microplate reader at $490 \mathrm{~nm}$.

Flow cytometer analysis. Osteoblasts $\left(1 \times 10^{6}\right.$ cells/well $)$ were seeded into 6-well plates and treated with $0.8 \mathrm{mmol} / 1 \mathrm{H}_{2} \mathrm{O}_{2}$ or $0.8 \mathrm{mmol} / 1 \mathrm{H}_{2} \mathrm{O}_{2}$ and parthenolide $(5,10$ and $20 \mu \mathrm{M})$ for $24 \mathrm{~h}$. Treated cells were washed with PBS and centrifuged at $1,000 \mathrm{x} \mathrm{g}$ for $5 \mathrm{mins}$ at $4^{\circ} \mathrm{C}$. The precipitate was re-suspended in $0.5 \mathrm{ml}$ binding buffer, including $5 \mu \mathrm{l}$ annexin V-fluoresce in isothiocyanate and propidium iodide (BD Biosciences) for
$20 \mathrm{~min}$ in the dark. The apoptotic rate was examined using a FACSCalibur flow cytometer (BD Biosciences) with CXP Analysis software version 2.2 (Beckman Coulter, Brea, CA, USA). Cells in the lower left quadrant of each picture correspond to normal cells (Annexin V/PI). Cells in right lower quadrant correspond to early apoptotic cells (Annexin V+/PI-). Cells in the right upper quadrant correspond to late apoptotic/dead cells (Annexin V+/PI+).

Statistical analysis. Results were analyzed using SPSS 13.0 (SPSS, Inc., Chicago, IL, USA), and the statistical significance was calculated using Student's paired t-test and one-way and/or multiple-comparison analysis of variance followed by Tukey's test. All data are presented as the mean \pm standard deviation of three repeated experiments. $\mathrm{P}<0.05$ was considered to indicate a statistically significant difference.

\section{Results}

Effect of parthenolide on osteoblast viability. Under the microscope, control osteoblasts were observed to be triangular, polygonal or irregular. The nuclei were elliptical with one or two nucleoli and black cytoplasmic particles were present. The dark nuclei in the cells were positive for ALP (Fig. 1A). Osteoblasts were treated with different concentrations of parthenolide $(0,5,10,15,20,25$ and $30 \mu \mathrm{M})$ for 24 and $48 \mathrm{~h}$. MTT assays were performed to examine osteoblast viability. The results indicated that parthenolide significantly improved osteoblast viability in a dose- and time-dependent manner $\left({ }^{* *} \mathrm{P}<0.01 ;{ }^{* * *} \mathrm{P}<0.001\right.$; Fig. 1B).

Effect of parthenolide on $\mathrm{H}_{2} \mathrm{O}_{2}$-induced osteoblasts. To examine the possible biological functions of parthenolide and $\mathrm{H}_{2} \mathrm{O}_{2}$ in osteoblasts, osteoblasts were treated with $0.8 \mathrm{mmol} / \mathrm{l}$ $\mathrm{H}_{2} \mathrm{O}_{2}$ or $0.8 \mathrm{mmol} / 1 \mathrm{H}_{2} \mathrm{O}_{2}$ and parthenolide $(5,10$ and $20 \mu \mathrm{M})$ for 12,24 and $48 \mathrm{~h}$. An MTT assay was performed to examine osteoblast viability in a $\mathrm{H}_{2} \mathrm{O}_{2}$ environment. Results indicated that $\mathrm{H}_{2} \mathrm{O}_{2}$ significantly decreased osteoblast viability, and this decrease was rescued by parthenolide in a dose- and time-dependent manner $\left({ }^{* * *} \mathrm{P}<0.001\right.$, Fig. 1C).

Parthenolide inhibits apoptosis in $\mathrm{H}_{2} \mathrm{O}_{2}$-induced osteoblasts. To further investigate the effect of parthenolide on $\mathrm{H}_{2} \mathrm{O}_{2}$-induced osteoblast apoptosis, flow cytometry was performed. $\mathrm{H}_{2} \mathrm{O}_{2}$ significantly increased the apoptotic rate in osteoblasts, and parthenolide significantly decreased the $\mathrm{H}_{2} \mathrm{O}_{2}$-induced increase in osteoblast apoptosis $\left({ }^{* * *} \mathrm{P}<0.001\right.$ vs.

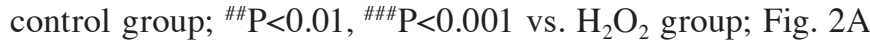
and $\mathrm{B})$. To further understand the molecular mechanism of the function of parthenolide, RT-qPCR and western blot analyses were used to analyze $\mathrm{Bax}$ and $\mathrm{Bcl}-2$ expression. The results revealed that $\mathrm{H}_{2} \mathrm{O}_{2}$ significantly increased the expression of Bax, and significantly decreased the expression of Bcl-2. Parthenolide significantly reversed the alterations observed in $\mathrm{H}_{2} \mathrm{O}_{2}$-induced osteoblasts ${ }^{* * *} \mathrm{P}<0.001$ vs. control group,

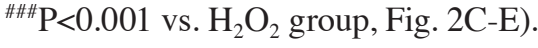

Parthenolide decreases the levels of ROS, MDA, LDH and ALP, andincreases $\mathrm{SOD}$ and GPXlevels in $\mathrm{H}_{2} \mathrm{O}_{2}$-inducedosteoblasts. Cellular apoptosis and proliferation are two important events 
A

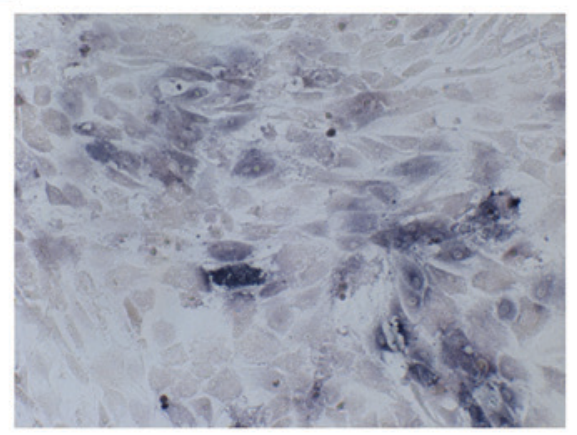

B

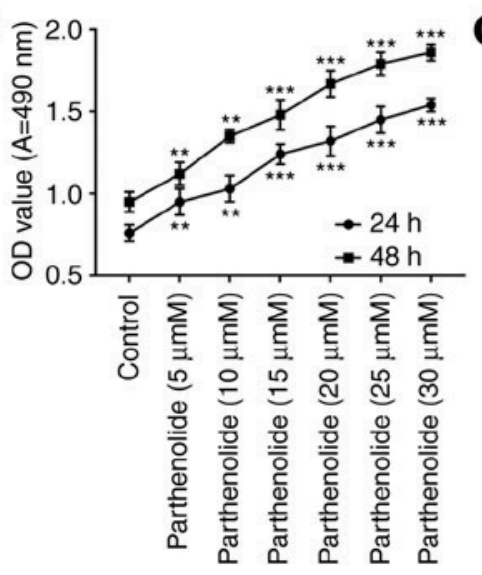

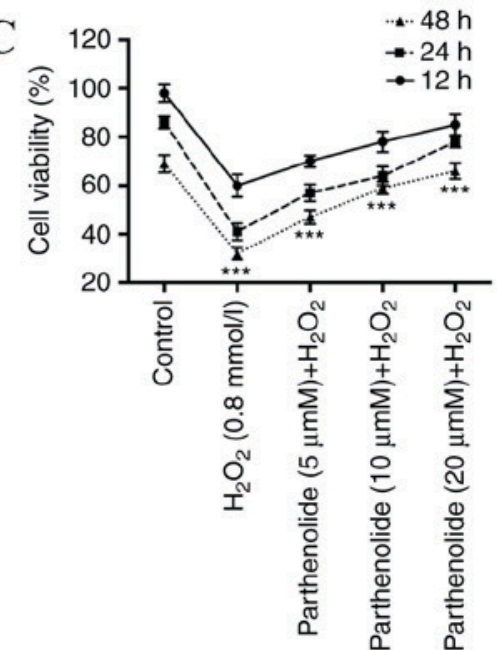

Figure 1. Protective effect of parthenolide on osteoblast cells. (A) Representative image of osteoblasts stained for alkaline phosphatase (magnification, x200). (B) Cell viability was measured by MTT assay in osteoblasts treated with increasing concentrations of parthenolide for 24 and $48 \mathrm{~h}$, and (C) osteoblasts treated with $\mathrm{H}_{2} \mathrm{O}_{2}$, and increasing concentrations of parthenolide, for 12,24 and $48 \mathrm{~h} .{ }^{* *} \mathrm{P}<0.01,{ }^{* * * *} \mathrm{P}<0.001$ vs. control group.

A

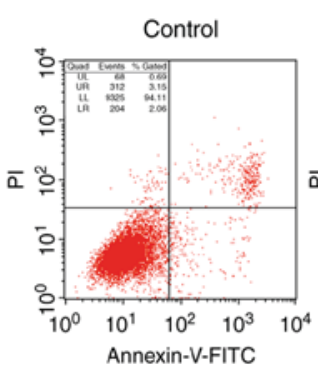

B $。$

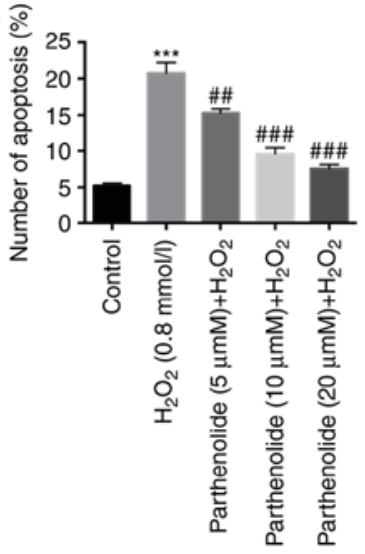

$\mathrm{H}_{2} \mathrm{O}_{2}(0.8 \mathrm{mmol} / \mathrm{l})$

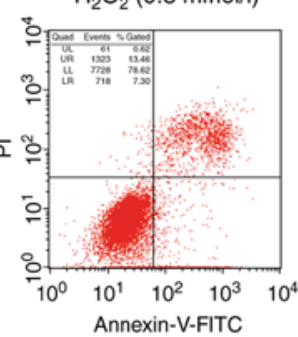

C

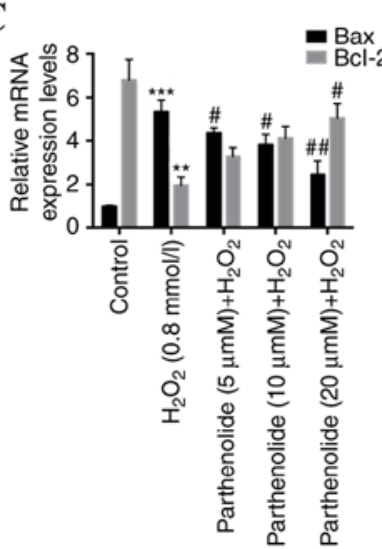

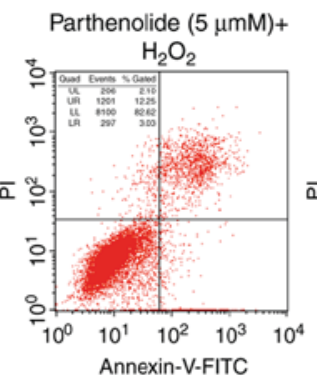

D

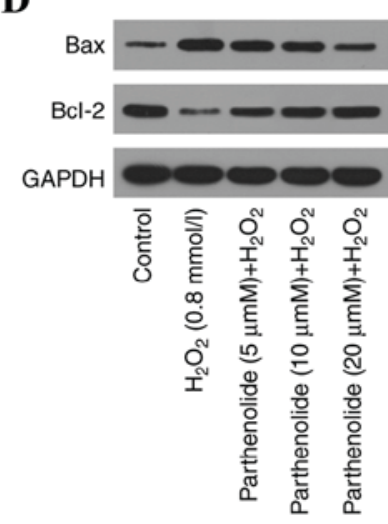

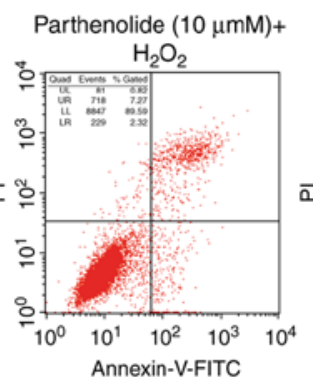

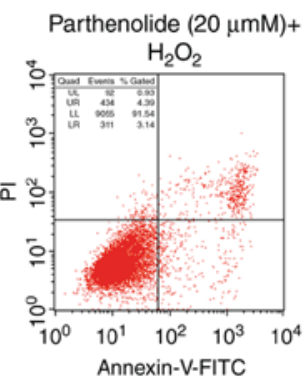

$\mathbf{E}$

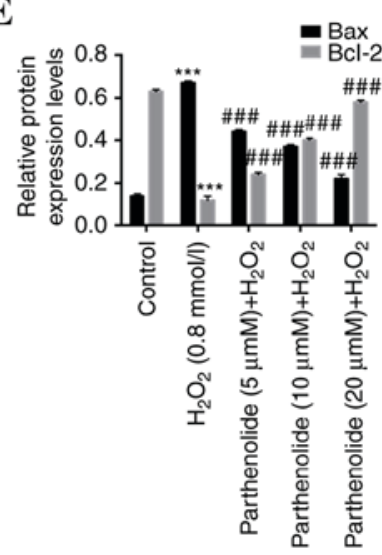

Figure 2. Parthenolide inhibits $\mathrm{H}_{2} \mathrm{O}_{2}$-inducedosteoblast apoptosis. Osteoblasts were treated with $0.8 \mathrm{mmol} / 1 \mathrm{H}_{2} \mathrm{O}_{2}$, or $0.8 \mathrm{mmol} / 1 \mathrm{H}_{2} \mathrm{O}_{2}$ and increasing concentrations of parthenolide for $24 \mathrm{~h}$. (A) Osteoblast apoptosis was analyzed by flow cytometry and (B) the apoptotic cell number was quantitatively counted. (C) Reverse transcription quantitative-polymerase chain reaction analysis was used to analyze Bax and Bcl-2 mRNA expression levels. (D) Western blot analysis was used to measure Bax and Bcl-2 protein expression levels. (E) Relative quantification of Bax and Bcl- 2 protein expression levels. ${ }^{* *} \mathrm{P}<0.01$, ${ }^{* * * *} \mathrm{P}<0.001$ vs. control group. ${ }^{\# \mathrm{P}}<0.05,{ }^{\# \#} \mathrm{P}<0.01,{ }^{\# \# \#} \mathrm{P}<0.001$ vs. $\mathrm{H}_{2} \mathrm{O}_{2}$ group. $\mathrm{Bcl}-2$, apoptosis regulator $\mathrm{Bcl}-2$; Bax, apoptosis regulator BAX; FITC, fluorescein isothiocyanate; PI, propidium iodide.

affected by oxidative stress (32-35). Numerous studies have demonstrated that ROS levels are closely associated with the induction of apoptosis in a number of pathophysiological conditions $(36,37)$. Oxidative stress may cause an imbalance between ROS and activity of antioxidative enzymes, including SOD and GPX (38). The influence of parthenolide and $\mathrm{H}_{2} \mathrm{O}_{2}$ on serum marker enzymes MDA, LDH and ALP was additionally investigated (39). Osteoblasts were treated with PBS,
$0.8 \mathrm{mmol} / 1 \mathrm{H}_{2} \mathrm{O}_{2}$ or $0.8 \mathrm{mmol} / 1 \mathrm{H}_{2} \mathrm{O}_{2}$ and parthenolide $(5,10$ and $20 \mu \mathrm{M}$ ) for $24 \mathrm{~h}$. The results indicated that $\mathrm{H}_{2} \mathrm{O}_{2}$ significantly increased ROS (Fig. 3A), MDA (Fig. 3C), LDH (Fig. 3D) and ALP (Fig. 3F) levels. SOD (Fig. 3B) and GPX (Fig. 3E) levels were significantly decreased. Parthenolide significantly reversed the alterations observed in $\mathrm{H}_{2} \mathrm{O}_{2}$-induced osteoblasts $\left({ }^{* * *} \mathrm{P}<0.001\right.$ vs. control group; ${ }^{\#} \mathrm{P}<0.05,{ }^{\# \#} \mathrm{P}<0.01,{ }^{\# \# \#} \mathrm{P}<0.001$ vs. $\mathrm{H}_{2} \mathrm{O}_{2}$ group). 

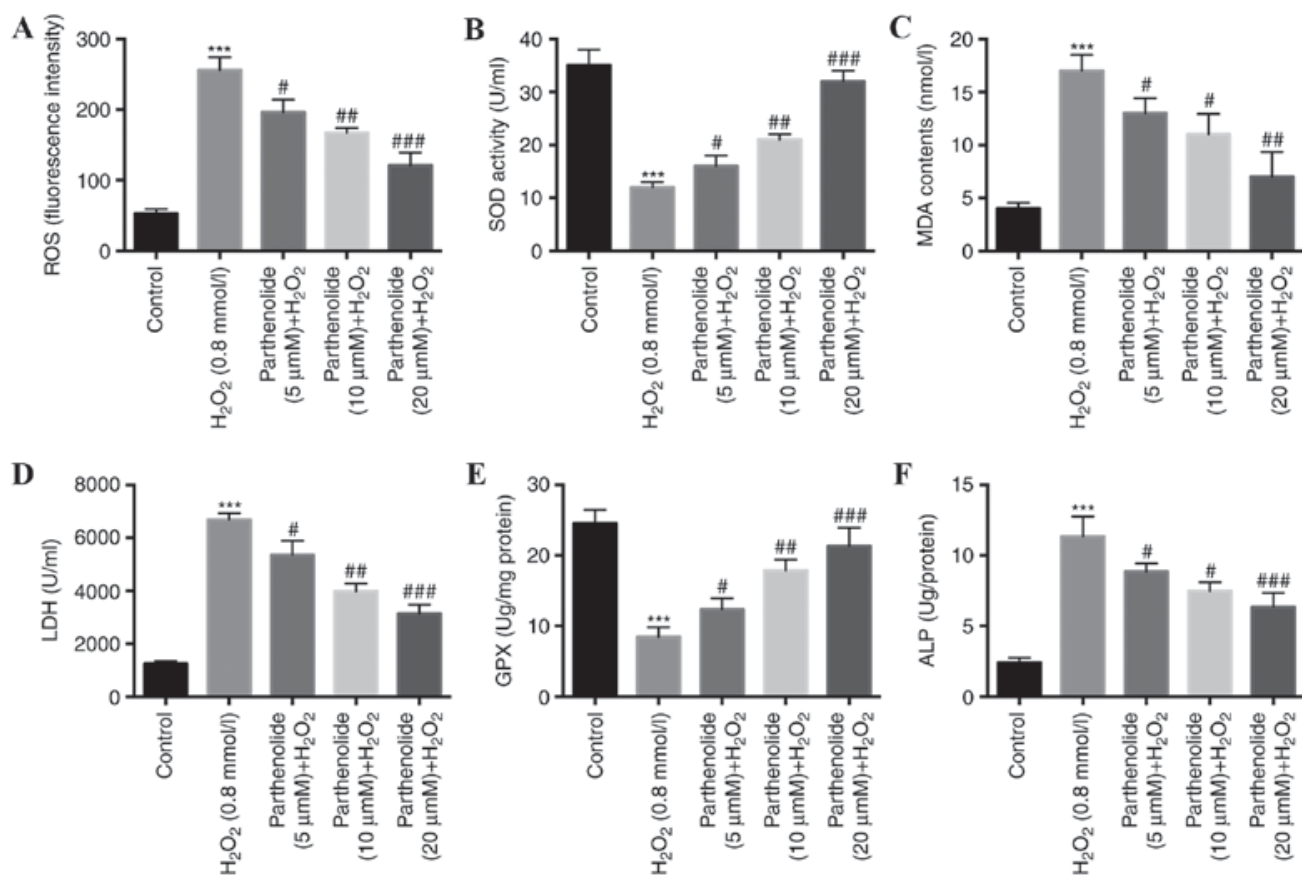

Figure 3. Parthenolide decreased the levels of ROS, MDA, LDH and ALP, and increased the levels of SOD and GPX in $\mathrm{H}_{2} \mathrm{O}_{2}$-induced osteoblasts. Osteoblasts were treated with $0.8 \mathrm{mmol} / 1 \mathrm{H}_{2} \mathrm{O}_{2}$ or $0.8 \mathrm{mmol} / 1 \mathrm{H}_{2} \mathrm{O}_{2}$ and parthenolide at increasing concentrations for $24 \mathrm{~h}$ (A) ROS fluorescence intensity was detected by flow cytometry with a fluorescence dye DHE. (B) SOD activity was determined with a colorimetric assay. (C) MDA activity was determined with a colorimetric assay. (D) LDH activity was determined with a cytotoxicity assay. (E) GPX activity was determined with a glutathione peroxidase cellular activity

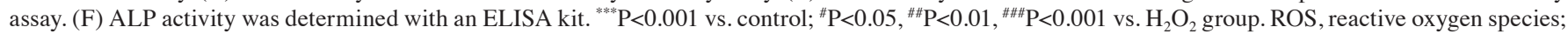
MDA, malondialdehyde; LDH, lactate dehydrogenase; ALP, alkaline phosphatase; SOD, superoxide dismutase; GPX, glutathione peroxidase.

Parthenolide upregulates osteogenesis-associated genes (Runx2, OPN, OCN, and Col-1) in osteoblasts, mediated by $\mathrm{H}_{2} \mathrm{O}_{2}$. It has been reported that Runx2, OPN, OCN, and Col-1 are key genes associated with osteogenesis (40). Therefore, the impact of parthenolide and $\mathrm{H}_{2} \mathrm{O}_{2}$ on the expression of these genes in osteoblasts was investigated. RT-qPCR and western blot analyses were performed to detect Runx2, OPN, OCN and Col-1 expression in treated osteoblasts. $\mathrm{H}_{2} \mathrm{O}_{2}$ was demonstrated to significantly inhibit Runx2, OPN, OCN, and Col-1 expression. Parthenolide rescued this $\mathrm{H}_{2} \mathrm{O}_{2}$-mediated inhibition $\left({ }^{* * *} \mathrm{P}<0.001\right.$ vs. control group; ${ }^{\#} \mathrm{P}<0.05$, ${ }^{\# \#} \mathrm{P}<0.01$,

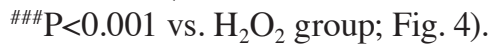

Parthenolide increases $\mathrm{Nrf2}, \mathrm{HO}-1$ and $\mathrm{NQO1}$ expression in osteoblasts, mediated by $\mathrm{H}_{2} \mathrm{O}_{2}$. The expression of $\mathrm{Nrf} 2$, HO-1 and NQO1 was measured by RT-qPCR and western blot analyses, to further elucidate the molecular mechanisms of action of parthenolide and $\mathrm{H}_{2} \mathrm{O}_{2}$ in osteoblasts. $\mathrm{H}_{2} \mathrm{O}_{2}$ was demonstrated to significantly decrease the expression of Nrf2, HO-1 and NQO1. Parthenolide reversed this decrease $\left({ }^{* * * *} \mathrm{P}<0.001\right.$ vs. control group; ${ }^{\#} \mathrm{P}<0.05,{ }^{\# \#} \mathrm{P}<0.01,{ }^{\# \# \#} \mathrm{P}<0.001$ vs. $\mathrm{H}_{2} \mathrm{O}_{2}$ group; Fig. 5).

\section{Discussion}

Large-scale and multi-directional osteoporosis research has made significant progress worldwide. The study of the effect of Chinese medicine in the process of bone collagen formation remains in its infancy, particularly in regards to the underlying molecular mechanisms (41). Tanacetum vulgare is an herbage used as a traditional Chinese medicine for its analgesic, antibacterial and anti-tumor properties; it is used to treat fever, migraine and joint pain (42). Tanacetum vulgare contains a variety of medicinal ingredients, including parthenolide, which is an active component of the sesquiterpene lactones (43). Recent studies have demonstrated that parthenolide has strong anti-tumor activity and may enhance the sensitivity of tumor cells to apoptosis signaling (44). The molecular mechanism of action of parthenolide in osteoporosis is unclear.

Oxidative stress is an inevitable condition in all organisms. A series of adaptive mechanisms exist to protect cells from damage, although various harmful stimuli may cause an imbalance in the equilibrium of oxidation, leading to the induction of apoptosis and even pathological damage (45). Oxidative stress may induce apoptosis through the mitochondrial, death receptor and endoplasmic reticulum stress pathways (46), in addition to through the activation of the protein kinase, nuclear factor- $\mathrm{\kappa B}$ and caspase pathways (47). It has been demonstrated that oxidative stress may be a risk factor associated with the development and progression of osteoporosis (48). Increasing evidence additionally suggests that ROS accumulation leads to oxidative stress under conditions of aging and certain illnesses or medicines, contributing to the development and progression of osteoporosis (49).

The present study demonstrated that parthenolide inhibited the decrease in osteoblast viability and the increase in apoptosis mediated by $\mathrm{H}_{2} \mathrm{O}_{2}$. Parthenolide additionally decreased Bax expression and increased $\mathrm{Bcl}-2$ expression in osteoblasts induced by $\mathrm{H}_{2} \mathrm{O}_{2}$. The expression of osteogenesis-associated genes Runx2, OPN, OCN and Col-1 was increased in $\mathrm{H}_{2} \mathrm{O}_{2}$-induced osteoblasts. Additionally, previous studies $(38,50)$ revealed that oxidative stress affects the activity 

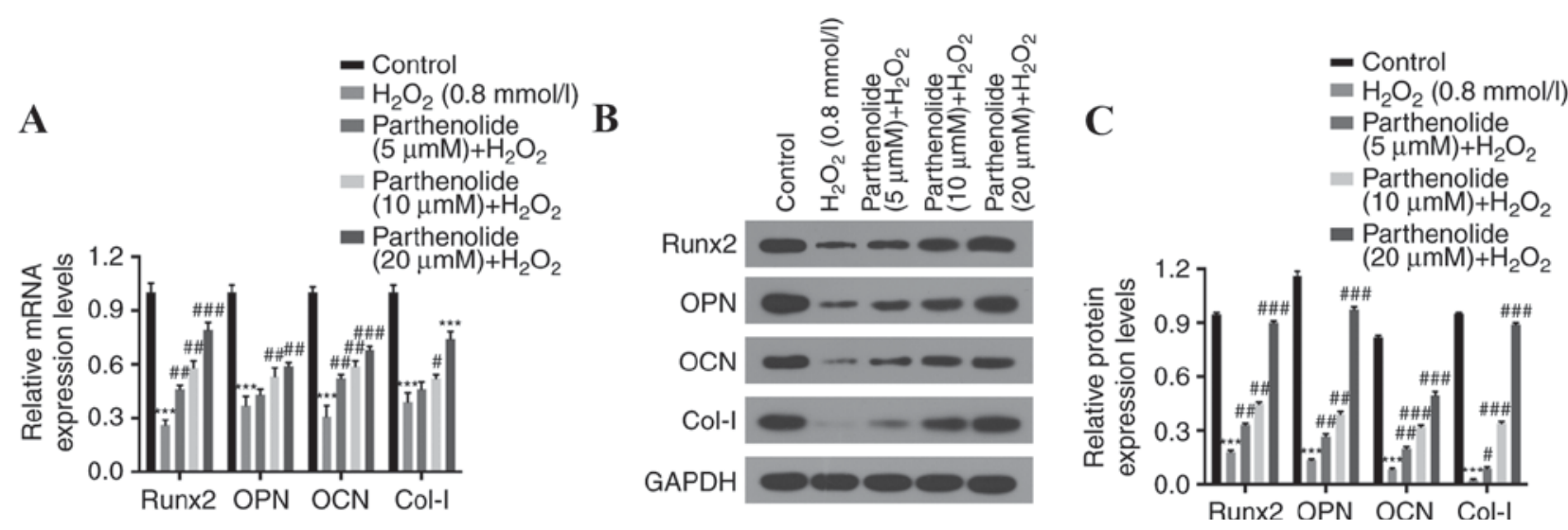

Figure 4. Parthenolide upregulates the osteogenesis-associated genes Runx2, OPN, OCN and Col-1 in $\mathrm{H}_{2} \mathrm{O}_{2}$-induced osteoblasts. Osteoblasts were treated with $0.8 \mathrm{mmol} / 1 \mathrm{H}_{2} \mathrm{O}_{2}$ or $0.8 \mathrm{mmol} / 1 \mathrm{H}_{2} \mathrm{O}_{2}$ and increasing concentrations of parthenolide for $24 \mathrm{~h}$. (A) Reverse transcription quantitative-polymerase chain reaction analysis was used to analyze Runx2, OPN, OCN, and Col-1 mRNA expression levels. (B) Protein expression levels were detected by western blot analysis and $(C)$ the relative quantification of proteins was calculated. ${ }^{* * * *} \mathrm{P}<0.001$ vs. control group; ${ }^{\#} \mathrm{P}<0.05,{ }^{\# \#} \mathrm{P}<0.01,{ }^{\# \# \#} \mathrm{P}<0.001$ vs. $\mathrm{H}_{2} \mathrm{O}_{2}$ group. Runx2, runt related transcription factor 2; OPN, osteopontin; OCN, osteocalcin; Col-1, collagen 1.
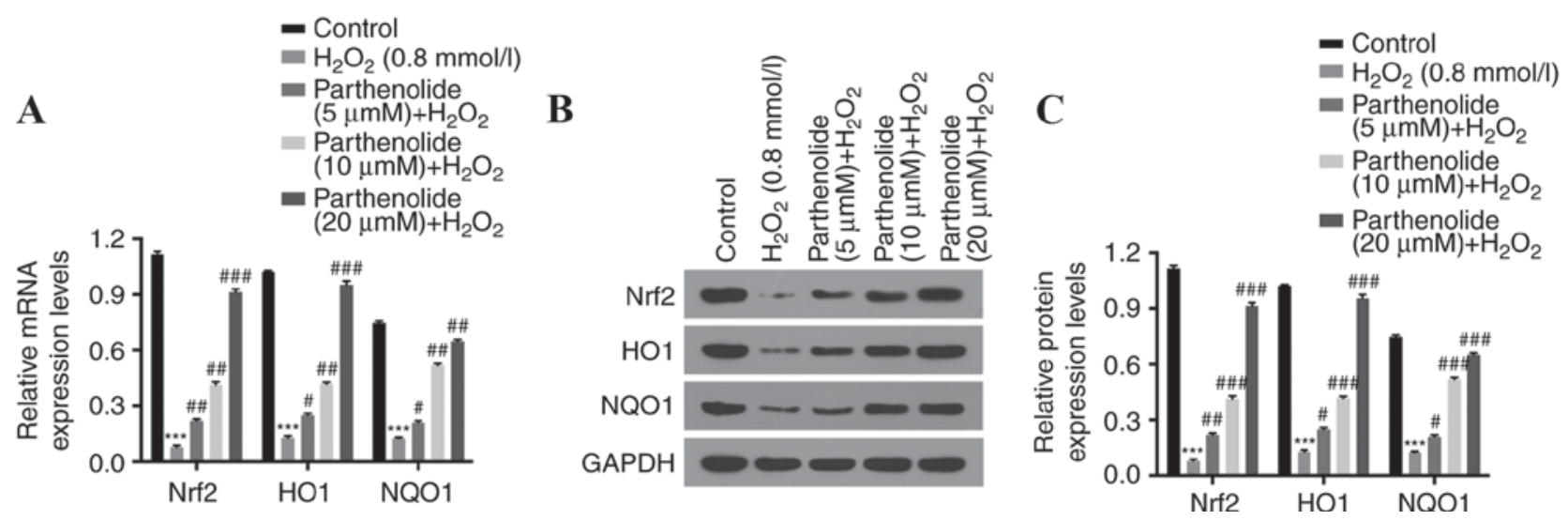

Figure 5. Parthenolide increases Nrf2, $\mathrm{HO}-1$ and NQO1 expression in $\mathrm{H}_{2} \mathrm{O}_{2}$-induced osteoblasts. Osteoblasts were treated with $0.8 \mathrm{mmol} / 1 \mathrm{H} \mathrm{O}_{2}$ or $0.8 \mathrm{mmol} / 1$ $\mathrm{H}_{2} \mathrm{O}_{2}$ and increasing concentrations of parthenolide for $24 \mathrm{~h}$. (A) Reverse transcription quantitative-polymerase chain reaction analysis was used to analyze Nrf2, HO-1 and NQO1 mRNA expression levels. (B) Protein expression levels were detected by western blot analysis and (C) the relative quantification of proteins was calculated. ${ }^{* * * *} \mathrm{P}<0.001$ vs. control group; ${ }^{*} \mathrm{P}<0.05,{ }^{\# \#} \mathrm{P}<0.01,{ }^{\# \# \#} \mathrm{P}<0.001$ vs. $\mathrm{H}_{2} \mathrm{O}_{2}$ group.

of the antioxidant enzymes SOD and GPX and serum marker enzymes MDA, LDH and ALP $(38,50)$. The present study demonstrated that parthenolide decreased the $\mathrm{H}_{2} \mathrm{O}_{2}$-induced increase in ROS, MDA, LDH, and ALP levels. SOD and GPX levels were also rescued in $\mathrm{H}_{2} \mathrm{O}_{2}$-induced osteoblasts.

A previous study indicated that parthenolide, a sesquiterpene lactone obtained from Tanacetum pathenium, has high antineoplastic activity (44). Parthenolide has been demonstrated to inhibit the growth and induce the death in vitro of numerous tumor cell types, including liver cancer, cholangiocarcinoma and multiple myeloma (44,51-53). Furthermore, parthenolide has been demonstrated to enhance the sensitivity of cancer cells to therapy, including liver cancer cell sensitivity to cisplatin $(54,55)$. The present study revealed that $\mathrm{H}_{2} \mathrm{O}_{2}$ increased Bax expression and decreased $\mathrm{Bcl}-2$ expression. Parthenolide significantly prevented these $\mathrm{H}_{2} \mathrm{O}_{2}$-mediated alterations in osteoblasts. A direct interaction may exist between parthenolide and $\mathrm{H}_{2} \mathrm{O}_{2}$ in the culture medium, and parthenolide may inhibit $\mathrm{H}_{2} \mathrm{O}_{2}$-induced apoptosis in osteoblasts.

$\mathrm{Nrf} 2$ is a transcription factor that regulates the intracellular metabolism of endogenous and exogenous substances in the oxidative stress response. Nrf2 binds to the antioxidant response element (1) and up-regulates ARE-associated antioxidative genes, including endogenous antioxidants, phase II detoxification enzymes and transcripts encoding intracellular genes that determine cell survival or death (56). The sustained expression of Nrf2 has important functions in restoring cellular homeostasis (57). A number of natural or synthetic small molecule compounds have been confirmed to activate the Nrf2/ARE signaling pathway, resulting in protection of cells from toxic or carcinogenic material-induced cell damage (58). Nrf2/ARE pathway activation results in the expression of cytoprotective enzymes, including NQO1 and HO-1 (58). Therefore, Nrf2 has an essential role in protection against oxidative stress. The results of the present study indicated that parthenolide increased Nrf2, HO-1 and NQO1 expression in $\mathrm{H}_{2} \mathrm{O}_{2}$-induced osteoblasts. Therefore, parthenolide may suppress osteoblast apoptosis by reducing oxidative stress.

In conclusion, the results of the present study confirmed that parthenolide increased viability and inhibited apoptosis in $\mathrm{H}_{2} \mathrm{O}_{2}$-induced osteoblasts. The decrease in apoptosis mediated by parthenolide may be via a reduction in oxidative stress. 
Additionally, parthenolide was demonstrated to increase the expression of the osteogenesis-associated genes Runx2, OPN, OCN and Col-1 in $\mathrm{H}_{2} \mathrm{O}_{2}$-induced osteoblasts. Therefore, parthenolide may have potential as a therapeutic drug for osteoporosis. Future studies are required to further validate the key findings of the present study. The effects of parthenolide may be verified in vivo in osteogenic tissues and a rat model under oxidative stress, and additional cell lines may be used to validate the important conclusions of the present study.

\section{Acknowledgements}

Not applicable.

\section{Funding}

No funding was received.

\section{Availability of data and materials}

All data generated and/or analyzed during this study are included in this published article.

\section{Authors' contributions}

$\mathrm{WM}$ wrote the main manuscript. $\mathrm{WM}$ and $\mathrm{ZZ}$ performed the experiments. WM and $\mathrm{ZZ}$ designed the study. $\mathrm{ZZ}$ performed data analysis. WM and ZZ contributed to manuscript revisions and all authors reviewed the manuscript.

\section{Ethics approval and consent to participate}

The study was approved by the Ethics Committee of the fifth People's Hospital of Yuhang District.

\section{Consent for publication}

Informed consent was approved by both the 8-year-old patient and his guardian.

\section{Competing interests}

The authors declare that they have no competing interests.

\section{References}

1. Marengoni A, Rizzuto D, Wang HX, Winblad B and Fratiglioni L: Patterns of chronic multimorbidity in the elderly population. J Am Geriatr Soc 57: 225-230, 2009.

2. Carmeliet G, Dermauw V and Bouillon R: Vitamin D signaling in calcium and bone homeostasis: A delicate balance. Best Pract Res Clin Endocrinol Metab 29: 621-631, 2015.

3. Reid IR, Bristow SM and Bolland MJ: Calcium supplements: Benefits and risks. J Int Med 278: 354-368, 2015

4. Ströhle A, Hadji P and Hahn A: Calcium and bone health-goodbye, calcium supplements? Climacteric 18: 702-714, 2015.

5. Davidovich P, Kearney CJ and Martin SJ: Inflammatory outcomes of apoptosis, necrosis and necroptosis. Biol Chem 395 1163-1171, 2014.

6. Elmore S: Apoptosis: A review of programmed cell death. Toxicol Pathol 35: 495-516, 2007.

7. Kamogashira T, Fujimoto C and Yamasoba T: Reactive oxygen species, apoptosis and mitochondrial dysfunction in hearing loss. Biomed Res Int 2015: 617207, 2015.
8. Baek KH, Oh KW, Lee WY, Lee SS, Kim MK, Kwon HS, Rhee EJ, Han JH, Song KH, Cha BY, et al: Association of oxidative stress with postmenopausal osteoporosis and the effects of hydrogen peroxide on osteoclast formation in human bone marrow cell cultures. Calcif Tissue Int 87: 226-235, 2010.

9. Mackinnon ES, Rao AV and Rao LG: Dietary restriction of lycopene for a period of one month resulted in significantly increased biomarkers of oxidative stress and bone resorption in postmenopausal women. J Nutr Health Aging 15: 133-138, 2011.

10. Callaway DA and Jiang JX: Reactive oxygen species and oxidative stress in osteoclastogenesis, skeletal aging and bone diseases. J Bone Miner Metab 33: 359-370, 2015.

11. Hamada Y, Fujii $\mathrm{H}$ and Fukagawa M: Role of oxidative stress in diabetic bone disorder. Bone 45 (Suppl 1): S35-S38,

12. Vela L, Contel M, Palomera L, Azaceta G and Marzo I: Iminophosphorane-organogold (III) complexes induce cell death through mitochondrial ROS production. J Inorg Biochem 105: 1306-1313, 2011.

13. D'Amico E, Factor-Litvak P, Santella RM and Mitsumoto H: Clinical perspective on oxidative stress in sporadic amyotrophic lateral sclerosis. Free Radic Biol Med 65: 509-527, 2013.

14. Ling F, Niu R, Hatakeyama H, Goto Y, Shibata T and Yoshida M: Reactive oxygen species stimulate mitochondrial allele segregation toward homoplasmy in human cells. Mol Biol Cell 27: 1684-1693, 2016.

15. Majid AS, Yin ZQ and Ji D: Sulphur antioxidants inhibit oxidative stress induced retinal ganglion cell death by scavenging reactive oxygen species but influence nuclear factor (erythroid-derived 2)-like 2 signalling pathway differently. Biol Pharm Bull 36: 1095-1110, 2013

16. Romiszewska A and Nowak-Stępniowska A: Photodynamic reaction and oxidative stress-influence of the photodynamic effect on the activity antioxidant enzymes. Postepy Biochemii 60: 355-364, 2014.

17. She C, Zhu LQ, Zhen YF, Wang XD and Dong QR: Activation of AMPK protects against hydrogen peroxide-induced osteoblast apoptosis through autophagy induction and NADPH maintenance: New implications for osteonecrosis treatment? Cell Signal 26: 1-8, 2014.

18. Harachikuma M, Watanabe S and Satooka H: Involvement of aquaporin-3 in epidermal growth factor receptor signaling via $\mathrm{H}_{2} \mathrm{O}_{2}$ transport in cancer cells. Biochem Biophys Res Commun 471: 603-609, 2016.

19. Holmström KM and Finkel T: Cellular mechanisms and physiological consequences of redox-dependent signalling. Nat Rev Mol Cell Biol 15: 411-421, 2014.

20. Yue Q, Gao G, Zou G, Yu H and Zheng X: Natural products as adjunctive treatment for pancreatic cancer: Recent trends and advancements. Biomed Res Int 2017: 8412508, 2017

21. Sun J, Zhang C, Bao YL, Wu Y, Chen ZL, Yu CL, Huang YX, Sun Y, Zheng LH, Wang X and Li YX: Parthenolide-induced apoptosis, autophagy and suppression of proliferation in HepG2 cells. Asian Pac J Cancer Prev 15: 4897-4902, 2014.

22. Uchibori R, Tsukahara T, Ohmine K and Ozawa K: Cancer gene therapy using mesenchymal stem cells. Int J Hematol 99: 377-382, 2014.

23. Zhou J, Zhang H, Gu P, Bai J, Margolick JB and Zhang Y: NF-kappaB pathway inhibitors preferentially inhibit breast cancer stem-like cells. Breast Cancer Res Treat 111: 419-427, 2008.

24. Diamanti P, Cox CV, Moppett JP and Blair A: Parthenolide eliminates leukemia-initiating cell populations and improves survival in xenografts of childhood acute lymphoblastic leukemia. Blood 121: 1384-1393, 2013.

25. Al Fatlawi AA, Al-Fatlawi AA, Irshad M, Rahisuddin and Ahmad A: Effect of parthenolide on growth and apoptosis regulatory genes of human cancer cell lines. Pharm Biol 53: 104-109, 2015.

26. Sang WK, Park ES and Lee CS: Parthenolide induces apoptosis by activating the mitochondrial and death receptor pathways and inhibits FAK-mediated cell invasion. Mol Cell Biochem 385: 133-144, 2013.

27. Livak KJ and Schmittgen TD: Analysis of relative gene expression data using real-time quantitative PCR and the 2(-Delta Delta C(T)) method. Methods 25: 402-408, 2001.

28. Shen Y, Guo W, Wang Z, Zhang Y,Zhong L and Zhu Y: Protective Effects of hydrogen sulfide in hypoxic human umbilical vein endothelial cells: A possible mitochondria-dependent pathway. Int J Mol Sci 14: 13093-13108, 2013. 
29. Mccord JM and Fridovich I: Superoxide dismutase. An enzymic function for erythrocuprein (hemocuprein). J Biol Chem 244: 6049-6055, 1969.

30. Cabaud PG and Wroblewski F: Colorimetric measurement of lactic dehydrogenase activity of body fluids. Am J Clin Pathol 30: 234-236, 1958.

31. Maseko T, Howell K, Dunshea FR and Ng K: Selenium-enriched Agaricus bisporus increases expression and activity of glutathione peroxidase- 1 and expression of glutathione peroxidase- 2 in rat colon. Food Chem 146: 327-333, 2014.

32. Can M, Guven B, Bektas S and Arikan I: Oxidative stress and apoptosis in preeclampsia. Tissue Cell 46: 477-481, 2014.

33. Jain S, Webster TJ, Sharma A and Basu B: Intracellular reactive oxidative stress, cell proliferation and apoptosis of Schwann cells on carbon nanofibrous substrates. Biomaterials 34: 4891-4901, 2013.

34. Vaz CV, Marques R, Maia CJ and Socorro S: Aging-associated changes in oxidative stress, cell proliferation and apoptosis are prevented in the prostate of transgenic rats overexpressing regucalcin. Transl Res 166: 693-705, 2015

35. Yen YH, Farooqi AA, Li KT, Butt G, Tang JY, Wu CY, Cheng YB, Hou MF and Chang HW: Methanolic extracts of solieria robusta inhibits proliferation of oral cancer ca9-22 cells via apoptosis and oxidative stress. Molecules 19: 18721-18732, 2014.

36. Simon HU, Hajyehia A and Levischaffer F: Role of reactive oxygen species (ROS) in apoptosis induction. Apoptosis 5: 415-418, 2000

37. Yee C, Yang W and Hekimi S: The intrinsic apoptosis pathway mediates the pro-longevity response to mitochondrial ROS in C. elegans. Cell 157: 897, 2014.

38. Sharma SS and Dietz KJ: The relationship between metal toxicity and cellular redox imbalance. Trends Plant Sci 14: 43-50, 2009.

39. Sivaramakrishnan V, Shilpa PN, Kumar VR and Devaraj SN: Attenuation of $\mathrm{N}$-nitrosodiethylamine-induced hepatocellular carcinogenesis by a novel flavonol-Morin. Chem Biol Interact 171: 79-88, 2008.

40. Wang Z, Feng Z, Wu G, Bai S, Yan D and Zhao Y: In vitro studies on human periodontal ligament stem cell sheets enhanced by enamel matrix derivative. Colloids Surf B Biointerfaces 141 102-111, 2016.

41. Rosen CJ and Bouxsein ML: Mechanisms of Disease: is osteoporosis the obesity of bone? Nat Clin Pract Rheumatol 2: 35-43, 2006.

42. Xie G, Schepetkin IA and Quinn MT: Immunomodulatory activity of acidic polysaccharides isolated from Tanacetum vulgare L. Int Immunopharmacol 7: 1639-1650, 2007.

43. Tiuman TS, Uedanakamura T, Garcia Cortez DA, Dias Filho BP, Morgado-Díaz JA, de Souza W and Nakamura CV: Antileishmanial activity of parthenolide, a sesquiterpene lactone isolated from tanacetum parthenium. Antimicrob Agents Chemother 49: 176-182, 2005.
44. Mathema VB, Koh YS, Thakuri BC and Sillanpää M: Parthenolide, a sesquiterpene lactone, expresses multiple anti-cancer and anti-inflammatory activities. Inflammation 35: 560-565, 2012.

45. Valko M, Morris H and Cronin MT: Metals, toxicity and oxidative stress. Curr Med Chem 12: 1161-1208, 2005.

46. Szegezdi E, Logue SE, Gorman AM and Samali A: Mediators of endoplasmic reticulum stress-induced apoptosis. EMBO Rep 7: 880-885, 2006

47. Manna SK, Sarkar S, Barr J, Wise K, Barrera EV, Jejelowo O, Rice-Ficht AC and Ramesh GT: Single-walled carbon nanotube induces oxidative stress and activates nuclear transcription factor- $\kappa \mathrm{B}$ in human keratinocytes. Nano Lett 5: 1676-1684, 2005.

48. Manolagas SC: From estrogen-centric to aging and oxidative stress: A revised perspective of the pathogenesis of osteoporosis. Endocr Rev 31: 266-300, 2010.

49. Doshi SB and Agarwal A: The role of oxidative stress in menopause. J Midlife Health 4: 140-146, 2013.

50. Kim Y, You Y, Yoon HG, Lee YH, Kim K, Lee J, Kim MS, Kim JC and Jun W: Hepatoprotective effects of fermented Curcuma longa L. on carbon tetrachloride-induced oxidative stress in rats. Food Chem 151: 148-153, 2014.

51. Pajak B, Gajkowska B and Orzechowski A: Molecular basis of parthenolide-dependent proapoptotic activity in cancer cells. Folia Histochem Cytobiol 46: 129-135, 2008.

52. Wyrębska A, Gach K and Janecka A: Combined effect of parthenolide and various anti-cancer drugs or anticancer candidate substances on malignant cells in vitro and in vivo. Mini Rev Med Chem 14: 222-228, 2014.

53. Kim JH, Liu L, Lee SO, Kim YT, You KR and Kim DG: Susceptibility of cholangiocarcinoma cells to parthenolide-induced apoptosis. Cancer Res 65: 6312-6320, 2005.

54. Fang LJ, Shao XT, Wang S, Lu GH, Tao X and Zhou JY: Sesquiterpene lactone parthenolide markedly enhances sensitivity of human A549 cells to low-dose oxaliplatin via inhibition of NF- $\kappa$ B activation and induction of apoptosis. Planta Med 76: 258-264, 2010

55. Kim SL, Liu YC, Park YR, Seo SY, Kim SH, Kim IH, Lee SO, Lee ST, Kim DG and Kim SW: Parthenolide enhances sensitivity of colorectal cancer cells to TRAIL by inducing death receptor 5 and promotes TRAIL-induced apoptosis. Int $\mathrm{J}$ Oncol 46: 1121-1130, 2015.

56. Michaeloudes C, Mercado N, Clarke C, Bhavsar PK, Adcock IM, Barnes PJ and Chung KF: Bromodomain and extraterminal proteins suppress NF-E2-related factor 2-mediated antioxidant gene expression. J Immunol 192: 4913-4920, 2014.

57. Paul MK, Bisht B, Darmawan DO, Chiou R, Ha VL, Wallace WD, Chon AT, Hegab AE, Grogan T, Elashoff DA, et al: Dynamic changes in intracellular ROS levels regulate airway basal stem cell homeostasis through Nrf2-dependent Notch signaling. Cell Stem Cell 15: 199-214, 2014.

58. Ma Q: Role of nrf2 in oxidative stress and toxicity. Annu Rev Pharmacol Toxicol 53: 401-426, 2013. 